\title{
PENGEMBANGAN BAHAN AJAR MATAKULIAH \\ PRAKTIKUM PENGANTAR AKUNTANSI DENGAN \\ PROGRAM MICROSOFT VISUAL BASIC
}

\author{
Endang Sri Andayani \\ Diana Tien Irafahmi \\ Sulastri \\ Universitas Negeri Malang \\ endanghandayani07@yahoo.co.id
}

\begin{abstract}
The research aims to develop a CD based accounting material using Visual Basic software. Such development is intended to enhance the quality of learning that can be characterized as to improve the accounting knowledge and skill to use computer. After completing a comprehensive review of expert judgment and pilot study, a CD based accounting material has been developed and installed in accounting students' computer. The material consist of 2 components: case and worksheet. Based on the result of expert validation and pilot test, the accounting material has fulfilled the criteria of "very good" and ready for use in a basic accounting practicum course.
\end{abstract}

Keywords: Learning material, Accounting, Compact Disk, Visual Basic

\begin{abstract}
Abstrak: Tujuan yang ingin dicapai dari kegiatan penelitian ini adalah tersusunnya bahan ajar praktikum akuntansi berbasis compact disk (CD) dengan menggunakan program Visual Basic yang mampu meningkatkan kualitas pembelajaran, yakni peningkatan pemahaman dan ketrampilan professional memanfaatkan teknologi komputer bagi mahasiswa. Setelah melalui serangkaian proses validasi uji coba dan pakar, dihasilkan bahan ajar praktikum Pengantar Akuntansi yang dikemas dalam bentuk compact disk yang kemudian diinstal pada komputer mahasiswa. Isi bahan ajar berbasis CD ini terdiri dari 2 komponen utama yaitu kasus dan kertas kerja. Hasil dari validasi dan uji coba menunjukkan bahwa bahan ajar praktikum ini telah memenuhi kriteria "sangat baik" dalam menyelesaikan kasus-kasus akuntansi dan valid atau siap untuk digunakan dalam matakuliah praktikum Pengantar Akuntansi.
\end{abstract}

Kata Kunci : Bahan Ajar, Akuntansi, Compact Disk, Visual Basic

Abad dua puluh dicirikan oleh kemajuan di bidang teknologi informasi dan komunikasi di segala aspek kehidupan kita. Kemajuan bidang teknologi informasi dan komunikas (Information and Communication Technology/ICT) 
telah memberikan peluang bagi dunia pendidikan untuk mngembangkan media dan bahan ajar yang lebih menarik dan adaptif sesuai dengan tuntutan globalisasi dan kemajuan teknologi. Kemampuan ICT untuk mengirim informasi secara cepat, tepat dan menarik dalam sebuah multimedia juga telah membuat pembelajar lebih menyenangkan. Hal ini penting mengingat skenario pembelajaran yang menyenangkan adalah kebutuhan untuk pembelajaran yang efektif. Selain menjadikan pembelajaran menyenangkan bagi siswa, pembelajaran yang efektif juga memampukan siswa untuk memperoleh ketrampilan, pengetahuan, dan sikap yang spesifik (Dick \& Reiser, 1989 dalam Tan \& Lim, 2008)

Program studi D3 Akuntansi, sebagai program studi vokasional bertujuan untuk menghasilkan tenaga ahli madya yang terampil di bidang akuntansi dan perpajakan. Untuk itu kemampuan praktis menjadi tuntutan guna menghasilkan tenaga akuntansi yang siap pakai di lapangan kerja. Untuk mencapai kompetensi tersebut, kegiatan perkuliahan dilakukan dengan strategi Problem Based Learning (PBL) dengan kasus-kasus perusahaan. Strategi tersebut dilakukan dengan memberikan kepada mahasiswa seperangkat bahan (paper based) berupa bukti transaksi, buku catatan jurnal, buku besar, dan format laporan keuangan dan secara manual mahasiswa menyelesaikan kasus tersebut.

Melihat praktik pembelajaran yang telah dilakukan tersebut, kegiatan pembelajaran hanya mampu melatih ketrampilan pembukuan secara manual, namun kurang memberikan ketrampilan yang sensitif terhadap perkembangan teknologi (khususnya teknologi komputer), dimana di era global pemanfaatan teknologi komputer akan menjadi bagian dari setiap aktivitas bisnis. Mengingat hampir setiap aktivitas bisnis dan kehidupan kita dimasa depan sangat bersentuhan dengan teknologi, maka pemberian bekal kompetensi akuntansi berbasis teknologi komputer menjadi sebuah tuntutan bagi lembaga pendidikan dalam menyiapkan tenaga terampil di era global.

Untuk memadukan kemampuan di bidang akuntansi dan ketrampilan di bidang teknologi komputer salah satunya dapat dilakukan dengan memberikan latihan secara terstruktur dan terus menerus berbagai kasus akuntansi dengan pendekatan penyelesaian berbasis teknologi komputer. Penelitian ini dilakukan 
untuk mengembangkan bahan ajar matakuliah praktikum akuntansi berbasis komputer dengan menggunakan program visual basic yang diharapkan mampu meningkatkan kemampuan mahasiswa menyelesaikan kasus-kasus akuntansi serta meningkatkan ketrampilan menggunakan teknologi komputer untuk memcahkan berbagai permasalahan di bidang akuntansi

Perkembangan teknologi informasi dan komunikasi berkembang dengan sangat pesat sebagai tuntutan globalisasi. Hal ini merubah paradigma pembelajaran di sekolah dan perguruan tinggi dari pembelajaran konvensional ke arah pembelajaran kontemporer yang sensitif terhadap teknologi. Dalam pembelajaran konvensional guru lebih banyak menggunakan alat bantu papan tulis dan buku teks terstandar untuk mencapai tujuan saat ini. Dalam sistem pendidikan konvensional tersebut, sekolah atau perguruan tinggi adalah lembaga pengajaran (teaching institution), bukan lembaga pembelajaran (learning institution). Secara singkat Barr dan Tag, 1995 (dalam Sadjad, 2008) menuliskan: "A College is an institution that exixts to provide instruction. Subtly but profoundly we are shifting to a new paradigm: A college is an institution that exists to produce learning".

Di era kompetisi global saat ini, pernyataan Barr dan Tag tersebut semakin mendapat perhatian tidak hanya dunia pendidikan di Amerika Serikat tetapi di negara - negara lain diseluruh dunia termasuk Indonesia. Pergeseran paradigma ini merebak ke segenap tingkatan sistem pendidikan dari pendidikan dasar sampai ke tingkat perguruan tinggi. Di era global dimana semakin tipis lintas batas negara, semakin pendek waktu, semakin dekat tempat dan semakin tinggi persaingan, maka pembelajaran konvensional dengan media papan tulis, pensil dan buku sudah tidak relevan lagi.

Dilihat dari segi perkembangan teknologi, media pembelajaran dapat dikelompokan menjadi dua yaitu media tradisional dan media teknologi mutakhir. Media tradisional dapat dibedakan menjadi visual diam yang diproyeksikan, visual yang tidak diproyeksikan, visual dinamis yang diproyeksikan, cetak, permainan dan realia. Sedangkan media teknologi mutakhir dibedakan menjadi media berbasis telekomunikasi dan media berbasis mikroprosesor. Sedangkan multimedia sebenarnya adalah suatu istilah generik bagi suatu media yang 
menggabungkan berbagai macam media baik untuk tujuan pembelajaran maupun bukan. Keragaman media ini meliputi teks, audio, animasi, video, bahkan simulasi.

Pemanfaatan teknologi informasi dan komunikasi dalam pengembangan media pembelajaran menjadi lebih beragam. Multimedia sebagai presentasi berbeda dari multimedia sebagai pembelajaran. Media presentasi tidak menuntuk pengguna berinteraksi secara aktif di dalamnya, kalaupun ada interaksi hanyalah interaksi yang samar (covert). Sedangkan media pembelajaran lebih melibatkan pengguna dalam aktivitas-aktivitas yang menuntut proses mental di dalam pembelajaran. Dari perspektif ini aktivitas mental spesifik yang dibutuhkan didalam terjadinya pembelajaran dapat dibangkitkan melalui manipulasi peristiwa-peristiwa instruksional (instructional events) yang sistematis. Jones 2000 (dalam Sadjad, 2008) menyatakan "teaching is about providing opportunities for students to learn”. Dari sinilah kemudian terjadi pergeseran orientasi pembelajaran dari pengajar (teacher oriented learning) ke peserta didik (student centered learning)

Tujuan utama dari pergeseran paradigma ini adalah agar lembaga pendidikan di semua tingkatan berhasil mengantar peserta didik agar menjadi lulusan yang "kompetitif" di era kompetisi global. Young (2006) menyatakan bahwa dalam pemanfaatan teknologi komputer, guru memiliki empat peran yaitu mendesaign lingkungan belajar, mengelola orang (manusia) dan sumber-sumber; memediasi belajar siswa; dan meningkatkan praktik - praktik yang telah dikembangkan dari literature dan observasi awal di kelas. Sejalan dengan perkembangan ICT, keragaman media seperti teks (tulisan), audio (media dengar), animasi, video (gambar hidup yang bergerak), bahkan simulasi dapat digantikan oleh komputer dan LCD. Multimedia ini memiliki beberapa keunggulan bila dibandingkan media - media lainnya seperti buku, audio, video atau televisi. Keunggulan paling menonjol yang dimiliki multimedia adalah interaktifitas. Bates, 1995 (dalam Pramono, 2008) menekankan bahwa diantara media-media lain interaktivitas multimedia atau media lain yang berbasis komputer adalah yang paling nyata (overt). Interaktivitas nyata disini adalah interaktivitas yang melibatkan fisik dan mental dari pengguna saat mencoba program multimedia. 
Matakuliah Praktikum Akuntansi berbasis CD pada dasrnya lebih mennekankan pencapaian kompetensi untuk ranah kognitif dan psikomotor. Pencapaian ranah kognitif lebih diarahkan pada peningkatan dan atau pemaantapan kompetensi memahami aturan dan dalil dalam akuntansi. Sedangkan pencapaian ranah psikomotor diarahkan pada kemampuan mahasiswa untuk memanfaatkan teknologi komputer untuk memmcahkan masalah-masalah akuntansi. Melalui matakuliah ini diharapkan mahasiswa memiliki pengalaman praktik menyelesaikan kasus-kasus akuntansi. Memberi pengalam praktis berarti memberi masukan wawasan dan ilmu pengetahuan dan psikomotor adalah tingkah laku dengan akhlak mulia serta pembinaan ketrampilan kepemimpinan yang visioner dan bijaksana.

Indikator kecakapan dari aspek psikomor meliputi: observing (memperhatikan); imitation (peniruan); practicing (pembiasan); dan adapting (penyesuaian). Sesuai pendapat ini maka pencapaian kompetensi psikomotor di bidang teknologi komputer, aktivitas latihan memegang peranan penting guna "mendarahdagingkan" kemampuan menggunakan teknologi tersebut. Tanpa latihan dan pembiasaan sangat tidak mugkin orang menguasai ketrampilan yang diinginkannya. Oleh karena itu di era teknologi informasi dan komunikasi, membiasakan setiap aktivitas belajar dengan selalu bersentuhan dengan teknologi tersebut (khususnya komputer) menjadi sangat penting.

Berbagai penelitian telah banyak dilakukan oleh penelitian sebelumnya tentang efektifitas penggunaan media yang diukur dari peningkatan hasil belajar. Penggunaan multimedia mengkombinasikan penggunaan teks, seni grafis, suara animasi, dan elemen video, mampu mensinkronkan belajar siswa (Lee Tiernan \& Grudin, 2001 dalam Tan \& Lim, 2008). Selain itu penggunaan multi media dalam sistem pendidikan saat ini diklaim secara luas dapat meningkatkan perhatian, kepercayaan dan kepuasan lebih tinggi untuk CBI/Computer Based Instruction (Rodgers \& Beverly, 2005), begitu pula membantu siswa untuk mendapatkan pengetahuan secara lebih efektif. Dengan media komputer kita dapat mengetahui bahwa siswa menggunakan gaya belajar yang berbeda dalam proses belajar mereka. 
Dalam penelitian ini baik kasus instruksi maupun kertas kerja menggunakan program komputer Microsoft Visual Basic. Microsoft Visual Basic (yang selanjutnya lebih dikenal dengan singkatan VB saja) merupakan sebuah bahasa pemrograman yang bersifat even driven dan menawarkan Integrated Development Environment (IDE) visual. Pemilihan program ini dikarenakan Visual Basic merupakan turunan bahasa BASIC dan menawarkan pengembangan aplikasi komputer berbasasis grafik dengan cepat. Akses ke basis data dalam Visual Basic menggunakan Data Acces Object (DAO), Remote Data Object (RDO), atau Activex Data Object (ADO) serta menawarkan pembuatan control ActiveX dan object ActivX.

Visual Basic menjadi populer karena kemudahan desain form secara visual serta adanya kemampuan untuk menggunakan komponen - komponen ActiveX yang dibuat oleh pihak lain. Disampin itu Visual Basic juga dapat digunakan untuk menguji program dan menghasilkan program akhir berektensi EXE yang langung dapat dihasilkan.

\section{METODE}

Tujuan yang ingin dicapai dari kegiatan ini adalah tersusunnya bahan ajar praktikum akuntansi berbasis CD dengan menggunakan program Visual Basic yang mampu meningkatkan kualitas pembelajaran, yakni peningkatan pemahaman dan ketrampilan akuntansi serta profesional pemanfaatan teknologi komputer.

Produk yang dihasilkan diharapkan memiliki spesifikasi: (a) bahan praktikum dikemas dalam bentuk Compact Disk, dimana dalam pembelajarannya CD ini diinstal ke dalam komputer mahasiswa; (b) isi bahan praktikum ini terbagi menjadi 2 bagian, yakni "kasus perusahaan" dan kertas kerja; (c) kasus perusahaan terbagi sesuai dengan isi pos-pos neraca disajikan dalam satu jendela, dimana mahasiswa dapat masuk ke dalam tiap kasus sesuai dengan yang diinginkannya; (d) Kertas kerja disajikan dalam jendela yang berbeda tyang terhubung dengan jendela kasusnya dan mahasiswa dapat membuka kasus kertas kerja sekaligus kasus dalam satu tampilan.

Untuk itu, pengembangan bahan ajar Praktikum Pengantar Akuntansi II dilakukan melalui tahapan: (a) mengembangkan materi Praktikum Pengantar 
Akuntansi II, yakni kasus-kasus akuntansi yans mendasar dan sederhana untuk semua pos neraca (Aktiva, Hutang dan Modal) beserta kertas kerjanya; (b) mengemaas materi praktikum dalam bentuk Compact Disk dengan menggunakan program Visual Basic; (c) validasi ahli (pakar) di bidang akuntansi dan pakar di bidang ICT terhadap praktikum yang telah dikemas dalam bentuk CD; (d) berdasar hasil validasi pakar, dilakukan revisi dan pengembangan bahan ajar serta (e) uji coba secara terbatas, untuk mengetahui tingkat kesulitan materi dan kendala yang dihadapi dalam mencapai kompetensi yang diharapkan; (f) finalisasi bahan ajar.

\section{HASIL DAN PEMBAHASAN}

\section{Hasil}

Bahan ajar yang dikembangkan memiliki spesifikasi dikemas dalam bentuk Compact Disk, dimana dalam pembelajarannya CD ini diinstal ke dalam komputer mahasiswa. Isi bahan praktikum ini terbagi menjadi 2 bagian, yakni “kasus perusahaan" dan kertas kerja. Terdapat 8 kasus dengan kertas kerja yang disesuaikan dengan topik per kasus. Kasus perusahaan terbagi sesuai dengan isi pos-pos neraca disajikan dalam satu jendela, dimana mahasiswa dapat masuk ke dalam tiap kasus sesuai dengan yang diinginkannya dan Kertas kerja disajikan dalam jendela yang berbeda yang terhubung dengan jendela kasusnya dan mahasiswa dapat membuka kasus kertas kerja sekaligus kasus dalam satu tampilan.

Proses validasi pakar dilakukan oleh 2 orang pakar, yaitu pakar informasi dan teknologi (IT) untuk melihat kelayakan bahan ajar dari sisi teknis, serta pakar akuntansi untuk melihat kelayakan bahan ajar dari sisi materi/content akuntansi. Interpretasi data hasil validasi pakar IT pada bahan ajar Praktikum Pengantar Akuntansi II menggunakan 3 kriteria teknis yaitu high (tinggi/sangat baik), medium (sedang/baik) dan low (rendah/kurang baik). Hasil validasi pakar IT sebagaimana dipaparkan pada tabel 1 menunjukkan bahwa secara umum bahan ajar praktikum pengantar akuntansi II ini layak dan masuk kriteria high (tinggi/sangat baik). 
Tabel 1. Hasil Validasi Produk Pengembangan (sisi teknis)

\begin{tabular}{cccc}
\hline No. & \multicolumn{1}{c}{ Aspek } & Kriteria & Keterangan \\
\hline 1. & Persyaratan system & High & Sangat baik \\
& $\begin{array}{l}\text { a. Proses instalasi mudah } \\
\text { b. Kompatibel dengan hardware }\end{array}$ & High & Sangat baik \\
c. Kompatibel dengan sistem operasi & High & Sangat baik \\
2. & & \\
& Navigasi & High & Sangat baik \\
& a. Petunjuk tiap langkah jelas $\quad$ Link antar screen jelas & High & Sangat baik \\
c. Program mudah dipelajari & High & Sangat baik \\
3. Design & & \\
a. Karakter-karakter di layar mudah dibaca & High & Sangat baik \\
b. Komposisi seimbang antara huruf, warna, & Medium & Baik \\
& dan bentuk $\quad$ Tombol print/save tersedia di tiap screen & High & Baik \\
d. Penggunaan gambar/tabel/grafik sesuai & Low & Rendah \\
\hline
\end{tabular}

Berdasarkan hasil validasi (tabel 1), bahan ajar yang dikembangkan mempunyai kelebihan seperti: (1) penggunaan CD bahan ajar praktikum PA II ini tidak membutuhkan persyaratan system yang rumit. Hal ini dapat diketahui dari proses instalasi yang mudah karena bahan ajar yang dikemas dalam CD tersebut kompatibel dengan hardware dan software yang ada di fakultas. Ini berarti bahwa tanpa penggunaan hardware/software tambahan, CD bahan ajar bisa langsung diinstal ke komputer; (2) Pengoperasian program sangat mudah karena terdapat petunjuk dan tombol navigasi yang jelas pada tiap layar, sehingga mahasiswa diharapkan dapat menggunakan bahan ajar tanpa panduan; (3) Pemilihan karakter di layar dilakukan secara cermat sehingga memudahkan mahasiswa membaca karakter-karakter tersebut serta memungkinkan mahasiswa tidak cepat merasa bosan dalam mengerjakan kasus pada bahan ajar praktikum PA II.

Walaupun demikian, sebagaimana yang diungkapkan oleh pakar IT, beberapa kekurangan utamanya dari sisi tampilan masih dijumpai pada produk pengembangan bahan ajar ini antara lain: (1) Penggunaan gambar pada kertas kerja dianggap kurang sesuai dengan substansi materi; (2) Komposisi warna screen yang dianggap kurang elegan. Berdasarkan evaluasi pakar IT tersebut, selanjutnya dilakukan revisi terhadap produk pengembangan terutama yang terkait dengan kelemahan, sebagaimana terlihat pada tabel 2 berikut. 
Tabel 2. Tampilan Produk Pengembangan Sebelum dan Sesudah Revisi

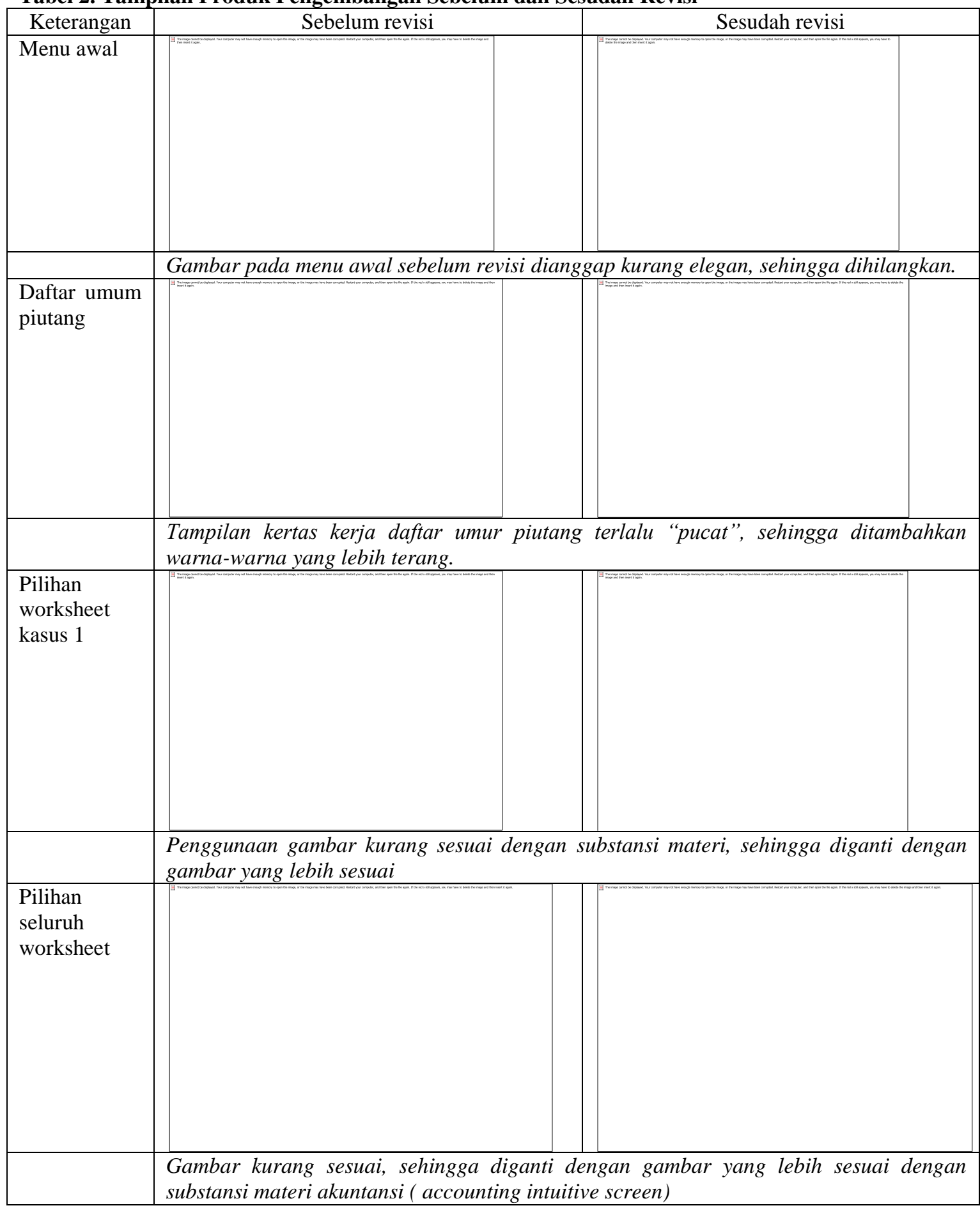

Interpretasi data hasil validasi pakar akuntansi pada bahan ajar Praktikum Pengantar Akuntansi II menggunakan 3 kriteria teknis yaitu sangat sesuai, sesuai dan kurang sesuai. Hasil validasi pakar akuntansi sebagaimana dipaparkan pada tabel 3 menunjukkan bahwa secara umum materi yang terangkum dalam bahan 
ajar praktikum pengantar akuntansi II ini layak dan masuk kriteria sesuai dengan kurikulum.

Tabel 3. Hasil Validasi Produk Pengembangan (sisi materi)

\begin{tabular}{|c|c|c|}
\hline No. & Aspek & Kriteria \\
\hline 1. & Cakupan materi & Sangat sesuai \\
\hline 2 & Tingkat kesulitan & Sesuai \\
\hline 3 & Variasi kasus & Sesuai \\
\hline 4 & Tingkat kejelasan kasus & Sangat sesuai \\
\hline 5 & Tingkat kejelasan instruksi kasus & Sesuai \\
\hline
\end{tabular}

Berdasarkan hasil validasi pakar akuntansi (tabel 3), bahan ajar yang dikembangkan mempunyai kelebihan seperti (1) Dilihat dari tingkat cakupan materi yang disajikan dalam bahan ajar (yakni kesesuaian tiap kasus dengan kompetensi yang akan dicapai dalam Matakuliah Praktikum Pengantar Akuntansi II) secara umum sangat sesuai dengan tujuan pembelajaran yang ingin dicapai. Ini berarti bahwa secara isi, kasus-kasus yang disajikan telah memenuhi harapan untuk membentuk kompetensi mahasiswa untuk Matakuliah Praktikum Pengantar Akuntansi II; (2) Dilihat dari tingkat kesulitan kasus yang disajikan dalam bahan ajar ini cukup sesuai. Artinya, kasus yang disajikan telah cukup memberi ketrampilan dan latihan berfikir kritis untuk memecahkan masalah-masalah pengakuan, penilaian dan penyajian pos-pos neraca. (3) Dilihat dari tingkat variasi kasus yang disajikan dalam bahan ajar relatif cukup variatif, walaupun untuk kasus aktiva tetap berwujud dan hutang lancar dikatakan sudah sangat variatif. (4) Dilihat dari tingkat kejelasan kasus yang disajikan dalam bahan ajar semua kasus sangat jelas. Artinya, paparan kasus dilihat dari segi bahasa mudah difahami dan tidak menimbulkan penafsiran ganda; dan (5) Dilihat dari tingkat kejelasan instruksi kasus yang disajikan dalam bahan ajar ini sudah cukup jelas, sehingga cukup memberikan arah kepada mahasiswa akan tugas yang harus diselesaikan dalam tiap kasus.

Meskipun demikian, terdapat beberapa hal yang masih dianggap kurang oleh pakar akuntansi adalah sebagai berikut: (1) Belum ada otomatisasi dalam penyelesaian siklus akuntansi, dimana seharusnya menurut pakar ada link langsung dari jurnal ke buku besar dan laporan keuangannya melalui mekanisme kode rekening. Namun menurut peneliti pengembang bahan ajar, model non otomatisasi ini sengaja dilakukan karena praktikum pengantar akuntansi II ini 
mengasah kemampuan mahasiswa untuk mengerjakan akuntansi akun-akun neraca dan tidak dimaksudkan untuk menyelesaikan satu siklus akuntansi; (2) Untuk PC atau Laptop dengan layar 12"/kurang tidak dapat digunakan untuk melihat seluruh tampilan. CD bahan ajar ini memang ditujukan untuk digunakan pada laboratorium komputer jurusan akuntansi yang menggunakan layar berukuran 14"/lebih. Oleh karena itu, CD bahan ajar sengaja dikembangkan agar hanya kompatibel dengan layar 14" atau layar yang berukuran lebih besar dari $14 "$.

Setelah melalui uji kelayakan dari pakar, maka dilakukan uji coba pada kelompok pemakai. Uji coba bahan Praktikum ini dilakukan terhadap mahasiswa peserta matakuliah Praktikum Pengantar Akuntansi II pada Semester II tahun 2009/2010. Mengingat matakuliah ini merupakan kelanjutan dari matakuliah sebelumnya, yakni Matakuliah Pengantar Akuntansi II, maka keberhasilan belajar matakuliah praktikum pengantar akuntansi II sangat ditentukan oleh tingkat pemahaman mahasiswa dalam matakuliah PA-II. Selain matakuliah Pengantar Akuntansi II, keberhasilan matakuliah Praktikum Akuntansi II dengan berbasis komputer ini juga sangat ditentukan oleh tingkat pemahaman dan ketrampilan mahasiswa dalam aplikasi komputer. Mahasiswa yang dijadikan sebagai subyek uji coba telah menempuh dan mengikuti ke dua matakuliah yang dimaksud.

Uji coba dilakukan di ruang Laboratorium Komputer Jurusan Akuntansi. Uji coba dilakukan atas bahan ajar yang telah direvisi sebagai hasil masukan dari para pakar. Jumlah topik kasus yang disajikan dalam bahan ajar ini meliputi kasus kas, piutang dagang, dan persediaan barang dagang, aktiva tetap, Hutang Lancar, Hutang Jangka Panjang, Ekuitas dan Laba Ditahan, serta Investasi. Uji coba terbatas dilakukan terhadap kasus kas dan piutang. pemilihan kasus yang dimaksud dikarenakan kasus tersebut relatif yang paling kompleks dibanding kasus yang lain. Dengan demikian diasumsikan, dengan memahami dan terampil menyelesaikan kasus yang dimaksud mahasiswa akan dengan mudah menggunakan bahan praktikum ini untuk kasus-kasus yang lain.

Hasil evaluasi yang dilakukan oleh mahasiswa peserta uji coba menunjukan bahwa secara umum bahan ajar ini memiliki keunggulan diantaranya: (a) tampilan menarik; (b) tampilan menu menggunakan bahasa Indonesia, 
memudahkan mahasiswa memahami perintah dan petunjuk penggunaan; (c) kertas kerja telah tersistem sesuai dengan urutan penyelesaian kasus; (d) mudah memasukan data dan mudah untuk memperbaiki pekerjaan yang salah; (e) setelah input data dapat secara langsung melihat tampilan; (f) tingkat kesulitan soal sudah bervariasi dan kasus yang disajikan telah menyeluruh sesuai dengan kompetensi dasar pada matakuliah Praktikum Pengantar Akuntansi II. Adapun kelemahan yang dapat diidentifikasi adalah: (1) dalam Jurnal Umum, jumlah baris yang tersedia sudah permanent, tidak bisa ditambah/dikurang, sehingga kurang fleksibel dalam pengerjaan; serta (2) belum tersedia menu tutorial (menu Help) pada tiap worksheet. Dari kelemahan yang teridentifikasi tersebut, kemudian dilakukan revisi sebagaimana terlihat pada tabel 4 berikut

Tabel 4. Tampilan Produk Pengembangan Sebelum dan Sesudah Revisi

\begin{tabular}{|c|c|}
\hline Keterangan & \begin{tabular}{|l|l|} 
Sebelum revisi & \\
\end{tabular} \\
\hline \multicolumn{2}{|l|}{ Jurnal umum } \\
\hline & $\begin{array}{l}\text { Jumlah baris pada jurnal umum sebelum revisi tidak dapat ditambah/dikurang, sehingga } \\
\text { digunakan model baru yaitu baris jurnal umum dapat ditambah/dikurang sesuai dengan } \\
\text { kebutuhan. }\end{array}$ \\
\hline \multicolumn{2}{|l|}{$\begin{array}{l}\text { Menu help } \\
\text { pada } \\
\text { worksheet }\end{array}$} \\
\hline & $\begin{array}{l}\text { Tidak ada petunjuk penggunaan worksheet, sehingga ditambahkan tombol petunjuk } \\
\text { penggunaan dengan symbol "?” yang jika di-klik langsung muncul kotak dialog } \\
\text { "petunjuk penggunaan" }\end{array}$ \\
\hline
\end{tabular}

Hasil evaluasi dan observasi dosen pengampu matakuliah Praktikum Pengantar Akuntansi II menunjukan bahwa jika dibandingkan dengan praktikum secara manual, selama proses praktikum, mahasiswa lebih termotivasi untuk menyelesaikan kasus karena terjadi interaksi timbal balik antara mahasiswa 
dengan program komputer (meliputi kasus serta kertas kerja). Selain itu bahan praktikum menjadi sangat simple sehingga tidak dibutuhkan buku dan kertas kerja yang sangat banyak yang sangat mengganggu proses kerja mahasiswa serta menyulitkan dalam penyimpanan. Namun demikian penggunaan bahan ajar ini sangat menuntut kemampuan mahasiswa dalam mengaplikasikan berbagai program komputer. Hal ini dapat dilihat selama proses uji coba, bagi mahasiswa yang memiliki ketrampilan komputer yang baik dapat dengan mudah mengaplikasikan program ini, demikian juga sebaliknya.

Seperti pada kegiatan perkuliahan praktikum manual, praktikum berbasis komputer ini juga diperlukan pendampingan dan monitoring dosen terhadap mahasiswa secara individu. Seperti halnya praktikum manual, penggunaan bahan ajar ini sangat memungkinkan terjadinya copy paste hasil unjuk kerja mahasiswa sehingga dapat mengurangi kualitas pembelajaran.

\section{Pembahasan}

Berdasarkan deskripsi hasil pengembangan diketahui bahwa bahan ajar yang dikembangkan dikemas dalam bentuk CD dan terdiri dari 2 bagian utama yaitu Kasus dan Kertas Kerja. Terdapat 8 kasus dengan kertas kerja yang disesuaikan dengan topik per kasus. Model bahan ajar dengan pendekatan kasus merupakan implementasi dari strategi Problem Based Learning dimana peserta didik dihadapkan pada beragam kasus/masalah riil perusahaan untuk dipecahkan sehingga mereka mampu memahami konsep dari serangkaian kegiatan pemecahan masalah tersebut. Ini berarti bahwa dengan mengerjakan kasus-kasus pada bahan ajar praktikum pengantar akuntansi 2 ini, mahasiswa diharapkan telah dapat belajar secara bermakna untuk meningkatkan pemahamannya. Selain itu bahan ajar ini juga dapat membantu melatih dan meningkatkan kemampuan psikomotorik mahasiswa dalam menggunakan piranti elektronik (komputer) karena bahan ajar ini dikemas dalam bentuk CD yang harus diinstal ke komputer. Penggunaan media pembelajaran berbasis teknologi komputer juga diharapkan dapat meningkatkan pemahaman mahasiswa terhadap materi praktikum pengantar akuntansi II secara lebih efektif. Bentuk bahan ajar yang paperless ini sekaligus 
menghilangkan kesan bahwa praktikum akuntansi harus dilakukan secara manual dan membutuhkan banyak kertas untuk mengerjakan.

Hasil evaluasi tersebut secara umum telah sesuai dengan tujuan penggunaan media komputer dalam pembelajaran. Media ini telah didesain dalam upaya menjadikan teknologi ini mampu memanipulasi keadaan sesungguhnya. Penekanannya terletak pada upaya yang berkesinambungan untuk memaksimalkan aktifitas belajar mengajar sebagai interaksi kognitif antara siswa, materi subjek, dan instruktur (dalam hal ini komputer yang diprogramkan). Sistem-sistem komputer dapat menyampaikan pembelajaran secara langsung kepada para siswa melalui cara berinteraksi dengan mata pelajaran yang diprogramkan kedalam sistem sehingga disebut pengajaran dengan bantuan komputer.

Tujuan dari pembelajaran Matakuliah Praktikum Pengantar Akuntansi II adalah memberikan pemahaman dan ketrampilan praktis tentang: pengendalian intern dan akuntansi untuk kas, piutang, persediaan, aktiva tetap dan penyusutan, sumber alam dan aktiva tidak berwujud, kewajiban lancar dan penggajian, kewajiban jangka panjang, investasi, modal, serta akuntansi untuk deviden-laba ditahan. Bahan ajar yang dikembangkan dengan menggunakan software Visual Basic ini dimaksudkan selain untuk meningkatkan kemampuan mahasiswa dalam menyelesaikan masalah pengakuan, pengukuran, penilaian dan pelaporan keuangan pos-pos neraca secara sederhana juga untuk meningkatkan ketrampilan mahasiswa dalam memanfaatkan teknologi informasi. Peningkatan kompetensi mahasiswa dibidang teknologi informasi menjadi sebuah tuntutan di era global dengan perkembangan ICT yang begitu pesat. Upaya peningkatan ketrampilan di bidang ICT dapat dilakukan melalui pembelajaran yang ramah terhadap adopsi ICT. Mahasiswa diharapkan akan mampu mengembangkan dan menggunakan aplikasi software (word processing, spreadsheets, and presentation graphics) serta software lain dalam penyelesaian proses akuntansi untuk mengurangi praktik akuntansi tradisional. Walaupun mahasiswa tidak diharapkan ahli dalam setiap bentuk IT, namun mereka akan mengembangkan beberapa kompetensi dalam tiap bidang pekerjaan yang mereka hadapi. 
Hasil uji coba juga menunjukkan bahwa penggunaan media komputer menjadi lebih menarik bagi mahasiswa dalam menyelesaikan kasus-kasus akuntansi jika dibandingkan dengan sistem manual (konvensional). Hal ini menunjukkan bahwa kriteria bahan ajar sebagai media pembelajaran multimedia telah terpenuhi, dimana salah satu tujuan penggunaan multimedia dalam pembelajaran adalah untuk mengurangi kelemahan dalam pembelajaran konvensional. Penggunaan multi media bermaksud untuk memanfaatkan apa saja yang tersedia di sekeliling siswa, di lingkungan sekolah dan perguruan tinggi maupun di luarnya, sebagai sumber belajar. Sebagaimana diungkapkan oleh Jones, 2000 (dalam Sadjad, 2008: 2) bahwa: "teaching is about providing opportunities for students to learn". Penelitian pengembangan bahan ajar ini telah berhasil membuat produk bahan ajar yang memberi kesempatan yang lebih luas pada mahasiswa untuk belajar akuntansi aset dengan cara yang lebih menyenangkan sekaligus mendekatkan mahasiswa pada piranti elektronik sebagai alternatif sumber belajar agar mereka menjadi lulusan yang "kompetitif" di era kompetisi global.

\section{SIMPULAN}

Produk hasil pengembangan bahan ajar berbasis komputer adalah berupa CD Praktikum Pengantar Akuntansi II yang terdiri dari 2 bagian utama yaitu kasus dan kertas kerja. Kasus disusun berdasarkan pendekatan akun - akun neraca, yaitu aktiva lancar (kas, piutang, persediaan), aktiva tetap dan investasi surat berharga, kewajiban serta ekuitas. Model bahan ajar dengan pendekatan kasus merupakan implementasi dari strategi Problem Based Learning dimana peserta didik dihadapkan pada beragam kasus/masalah riil perusahaan untuk dipecahkan sehingga diharapkan telah dapat belajar secara bermakna melalui serangkaian kegiatan pemecahan masalah tersebut. Jenis - jenis kertas kerja yang tersedia sesuai dengan kasus yang ada, yaitu jurnal umum, rekonsiliasi bank, buku pembelian, buku penjualan, buku besar, tabel depresiasi, daftar umur piutang, neraca, pembagian laba bersih, kartu persediaan dan lembar perhitungan jumlah saham beredar. 
Hasil uji kelayakan bahan ajar yang dilakukan oleh pakar di bidang IT dan akuntansi menunjukan bahwa bahan ajar telah memenuhi kriteria teknis dan akademis. Hasil uji coba juga menunjukan bahwa penggunaan bahan ajar ini mampu meningkatkan motivasi dan semangat mahasiswa dalam menyelesaikan kasus - kasus akuntansi, karena ada interaksi aktif antara mahasiswa dengan komputer. Namun demikian, dalam pelaksanaan pembelajaran masih diperlukan peran dosen sebagai fasilitator dan rujukan mahasiswa jika mengalami kesulitan dalam memahami dan menyelesaikan kasus dalam bahan ajar. Bahan ajar ini dikembangkan tidak untuk meniadakan peran dosen.

Dalam penelitian ini, prosedur pengembangan dan interpretasi terhadap produk pengembangan diarahkan pada kelayakan prototype produk. Penelitian ini belum menguji efektivitas produk pengembangan. Ini berarti bahwa masih terbuka kesempatan bagi penelitian lanjutan untuk meneliti apakah produk bahan ajar ini efektif untuk meningkatkan pemahaman dan prestasi mahasiswa pada matakuliah Praktikum Pengantar Akuntansi II.

\section{DAFTAR RUJUKAN}

Young, Hartnell Elizabeth. 2006. Teachers Roles and Professional Learning in Communities of Practice Supported by technology in Schools. Journal of Technology and Teacher Education. Vol. 14. No. 3. p. 461

Pramono, Gatot. 2008. Pemanfaatan Multimedia Pembelajaran. Modul. Pusat Teknologi Informasi dan Komunikasi Pendidikan. Departemen Pendidikan Nasional

Rodgers, L. David \& Beverly, J. Withrow Thorton. 2005. The Effect Of Instructional Media On Learner Motivation. International Journal of Instructional Media. Vol. 32. No. 4. p. 333

Sadjad, Rhiza S. 2008. Globalisasi, Sistem Pembelajaran dan Internet. http://www.unhas.ac.id/-rhiza/

Tan, Teow Ghee \& Lim, Teck Heng. 2008. Efficiency of Multimedia Teaching Instruction in Elementery Mandarin Class. Proceedings of CLASIC MARA University of Technology Malaysia. 
